\title{
FIRM PERFORMANCE AND CONDENSED CORPORATE GOVERNANCE MECHANISM: EVIDENCE OF NIGERIAN FINANCIAL INSTITUTIONS
}

\author{
Alex ADEGBOYE ${ }^{1}$, Stephen OJEKA ${ }^{2}$, Kofo ADEGBOYE ${ }^{3}$, \\ Emmanuel EBUZOR ${ }^{4}$, Dayo SAMSON ${ }^{5}$ \\ 1, 2, 4, 5 Department of Accounting, Covenant University, Ota, Ogun State, Nigeria \\ ${ }^{3}$ Department of Management and Accounting, Obafemi Awolowo University, Ile-Ife, Osun State, Nigeria \\ E-mails: ${ }^{1}$ adegboyea1@gmail.com (corresponding author); ${ }^{2}$ stephen.ojeka@covenantuniversity.edu.ng; \\ ${ }^{3}$ Kofoadegboye2@gmail.com; ${ }^{4}$ ebuzore@gmail.com; ${ }^{5}$ scholardayo01@yahoo.com
}

Received 12 February 2019; accepted 27 May 2019

\begin{abstract}
This paper extends the prior studies on corporate performance by empirically exploring the impact of overall corporate governance structure on firm performance. To unveil the objective of this study, firstly corporate governance index is built using Principal Component Analysis with 6 (six) identified corporate governance mechanisms from prior studies and then examines its effect on firms' performance. This study draws a sample of twenty-four (24) financial companies from the listed financial institutions in Nigeria for the period of 2013-2017. The formulated hypotheses are tested by employing static panel data estimators that are Fixed effect and Random Effect Regression. The results reveal that while controlling for firms' characteristics, constructed corporate governance indicator has a significant and negative influence on the firm performance measured by Return on Asset and Return on Equity. This finding supports that larger board, larger board committees and significant executive involvement have a detrimental influence on the performance of firms. The result implies a weak corporate governance structure is detrimental to higher financial performance amidst the weak institutions characterized in Nigeria context. That is, weaker corporate governance exhibits lower financial performance. This study then recommends that the corporate governance structure in Nigeria listed firms should be review with the intention to enhance the firm performance. Furthermore, it encourages the regulatory agencies like Central Bank of Nigeria, National Insurance Commission and Securities and Exchange Commission, to monitor the compliance of the listed firms to good governance endeavour.
\end{abstract}

Keywords: Corporate governance index, return on equity, return on asset, principal component analysis.

JEL Classification: G32, G34, M14, M42.

\section{Introduction}

This paper extends the prior studies on corporate performance by empirically exploring the impact of overall corporate governance structure on firm performance. Corporate governance dynamism has evolved over the years with the response to prior corporate failures and crises (Ojeka et al. 2015). According to the World Bank Report, the first welldocumented corporate governance failure can be traced to the "South Sea Bubble" of the 1700s, which transformed England's business practices and laws. Equivalently, the stock market crisis of 1929 revolutionized the securities laws of the United States. In addition, further crises such as United
Kingdom 1970s seconding banking crisis, the saving and loan default of 1980s in the United States, 1998 Russia financial crisis, Asia 1997-1998 financial crisis, the 2008 global financial crisis, recently the Brexit uncertainties, US tradewar with China and presidential policies, have triggered the concurrent development of corporate governance structure globally. All these have necessitated the importance of corporate governance for global sustainability and prosperity (Pillai and Al-Malkawi 2017).

Similar to other developing economies, financial institutions tend to play an imperative role in Nigeria. Therefore, it is necessary to evaluate the extent of financial institutions'

Copyright $\odot 2019$ The Authors. Published by VGTU Press.

This is an Open Access article distributed under the terms of the Creative Commons Attribution License (http://creativecommons.org/licenses/by/4.0/), which permits unrestricted use, distribution, and reproduction in any medium, provided the original author and source are credited.. 
contributions to the growing economies. Developing countries are characterized by weak institutions in which adopted corporate governance structure may be voluntary with limited benefits (Adegbite 2015a, Love and Rachinsky 2015). In the Nigeria context, the weak institution makes corporate law enforcement and self-regulatory initiative a mirage (Adegbite 2015a, Ojeka et al. 2019). In addition, Nigeria provides empirical insight due to the individuality of its corporate governance structure compared to the Anglo-American system, which is frequently researched by scholars. For instance, the corporate governance structure is often developed by the founding families who tend to maintain control on boards and the executive teams. This study then examines the level of corporate governance structure on the performance of firms amidst the weak institutions in Nigeria context.

Globally, good corporate governance as a fundamental principle is recognized to sustain the firms' performance, which has increasingly gained the interest of researchers, academic and practitioners. Interestingly, a strand of prior studies has examined different corporate governance indicators on performance of firms in both developed and developing countries (Ahmed and Hamdan 2015, Detthamrong et al. 2017, Ducassy and Guyot 2017, Emile et al. 2014, Huang and Kang 2017a, 2017b). Those studies exhibit mixed conclusions. Studies such as Caprio et al. (2007), Cornett et al. (2009), Rezaee (2008) emphasize that frailer corporate governance can negatively influence the firms' performance, valuation and may exhibit aggressive earning management characteristics. In addition, firms with weak governance characteristics may fail to embark on incentives that could enhance shareholders wealth (Diamond and Rajan 2008). However, prior studies also confirm that strong corporate governance is allied with higher financial performance such as Tobin's $\mathrm{Q}$, return on asset (ROA) and return on equity (ROE) (Zagorchev and Gao 2015, Akhigbe and Martin 2008).

Notably, prior studies examining the extent of diverse corporate governance mechanisms on both accounting and economic measures have inconsistent results. Larcker et al. (2007) affirm that the mixed results might be attributable to exertion in obtaining consistent measures for corporate governance construct. For instance, Yermack (1996) suggests a large board size diminishes the financial performance of firms while Dalton et al. (1999), uphold that large board composition enables the firm to attract more expertise skills and available resources. Therefore, it is necessary to measure corporate governance system with a reliable construct. Similarly, prior studies have introduced diverse corporate governance proxies into their methodology, which could increase explanatory power but might constitute statistical inconsistency (Tarchouna et al. 2017a).
The statistical problems occur due to complementarily interaction between corporate governance measurements (Ameziane Lasfer 2006, Florackis 2006). Consequently, the complementary relations amidst the corporate governance proxies could overload the model, which influence its reliability and limit researchers' conclusion (Tarchouna et al. 2017a).

To overcome the identified problems, prior studies have suggested the construction of a single mechanism that depicts the overall corporate governance structure. The linear correlation between various corporate governance constructs can be condensed to a unique index representing the overall corporate governance system since the mechanisms are implemented to address the agency problems (Allen et al. 2018, Lakshan and Wijekoon 2012, Matei and Drumasu 2015, Qian and Yeung 2015). Hence, the developed corporate governance index focuses on the overall mechanism, which mitigates agency problems. While effective corporate governance mechanisms can enhance maximize value, mitigate risk exposure, promote operational efficiency and ensure public accountability, few works of literature have developed corporate governance index to checkmate its effect on firm stability.

This study primarily examines the effect of corporate governance structure and firm characteristics on the firm financial performance. To unveil the objective of the study, two steps are charted. At first, the study constructs a corporate governance index for listed financial firms in Nigeria by condensing six (6) identified corporate governance mechanisms. The corporate governance index is built using Principal Component Analysis consistent with the significant corporate governance proxies identified by prior studies (Larcker et al. 2007, Love and Rachinsky 2015, Tarchouna et al. 2017a, Zagorchev and Gao 2016). The second step then adopts static panel data estimators via OLS, fixed and random effect analysis to analyse the influence of the built corporate governance index on the performance of firms. This study further contributes to prior knowledge of these underlined ways. First, to the best knowledge of the authors, this study pioneers the construction of condensed corporate governance variables using Principal Component Analysis in Nigerian corporate governance literature. This tends to reconcile the mixed results of the influence of corporate governance characteristics on the firms' performance. Finally, our findings will definitely help policy-makers to verify the outcome of provisions of the Code of Corporate Governance on Firms' Performance.

Section 2 of this study reviews the previous literature and develop our hypothesis. Section 3 of this study stipulates the methodology. Then, the empirical results are reported in Section 4. The findings of the study are discussed in Section 5 and then conclude. 


\section{Why the emphasis on financial institutions?}

Studies have emphasized the differences in corporate governance for financial institutions from overall corporate governance systems. For example, the scope of corporate governance for a financial institution is not only limited to shareholders but also include debtholder, blockholders, insurance policyholders and other creditors (Hopt 2013). In addition, financial institutions differ significantly from non-financial institutions due to the level of regulations, the banks' capital structure and the complexity of the business structure and opacity (Haan and Vlahu 2012, Zagorchev and Gao 2015).

Similarly, agency theory asserts that managers tend to have a lower risk appetite compared to shareholders because of the short-term benefits of control and undiversifiable humanoid capital investments of the firm (Faleye and Krishnan 2010). Interestingly in the case of bank bankruptcy, managers also have the tendency to lose invested wealth in the firm (Devriese et al. 2004). Generally, financial institutions are more leveraged compared to non-financial institutions in which the level of board risk appetite to maximize shareholders wealth could increase the chance of fiasco. However, financial institutions are exposed to various financial risks such as credit, interest rate and counterparty risks, which reflects their exclusive position as financial intermediaries. Thus, the excessive risk appetite of banks could have significant negative externalities on the macroeconomic and systemic risk, which encourage a highly regulated environment for financial institutions (Haan and Vlahu 2012, Ojeka et al. 2019). Recently, corporate collapses have contributed significantly to the financial market insecurity globally, which has triggered diverse regulatory responses (Salim et al. 2016).

Notably, financial institutions are characterized to have highly information asymmetries and more opacity than non-financial firms (Zagorchev and Gao 2015). The authors claim that "banks can change the mix and hide the quality of their assets rather quickly compared to non-financial firms." This shows the level of insider dealing in financial institutions leading to agency problems. Interestingly, recent legislation and supervision of the institutions tend to alleviate some of the problems. Prior studies affirm the higher level of trading assets and banks' imperviousness during the financial predicament compared to the non-crisis period (Flannery et al. 2013).

\section{Literature review and theoretical framework}

This study is anchored on the agency theory. The theory affirms that management and owners' separations exist in which the agents' performance could beneath the principal expectations. The divergence of managers and shareholders' interest could lead to a possible conflict of interest. The existence of the divergence of interest between the principals and agents are conceptualized and explored by the agency theory (Fama and Jensen 1983; Jensen and Meckling 1976). The theory defines the interrelationship between the shareholders and management (Waweru 2010), where the management activities such as information asymmetries and self-interest motivations can exhibit divergence from the overall shareholders' interest (Fama and Jensen 1983). In the occurrence of ownership and control separation, the shareholders' transfer decision control to the management, which could lead to conflict as the shareholders perceive the divergence of their interest with the management actions (Khan 2011). In the possible interest discrepancy, shareholders employ an internal monitory system to induce the management to increase the shareholders' wealth while improving the performance of the firm (Florackis and Ozkan 2009b). Therefore, deliberate monitory and control system is implemented by the shareholders to curb any potential problems and compliment the positive performance of the management. Presuming the agency costs to eliminate any element of conflict of interest at the expense of the shareholders, agency costs tend to curb agency problem while it retrogressively contributes to the performance of the firms (Ducassy and Guyot 2017).

\subsection{Corporate governance characteristics and performance of the firm}

Corporate governance structure encourages accountability and transparency with the aim to curb agency problem where there is the existence of separation between the management and shareholders. The corporate governance system is channeled towards the actualization of the firm's objectives through supervision and effective management. Prior studies have mixed findings on the corporate governance mechanisms on firm performance.

Zagorchev and Gao (2015) evaluate the extent of risk appetite and the performance of financial institutions in the United States relative to corporate governance system for period 2002-2009. Their results reveal a linear relationship between better corporate governance and higher firm values, while corporate governance is associated with a lower level of non-performing loans and higher market value (Tobin's $\mathrm{Q}$ ). This avers sound governance mechanisms are likely to lower the risk appetite of the management, which retrogressively has a positive influence on the performance of financial institutions that is consistent with the affirmations of Lemmon and Lins (2003), Akhigbe and Martin (2008). Salim et al. (2016) provide empirical findings of the connotation between corporate governance and the Australian banks' efficiency for the period 1999 and 2013, adopting two-stage double-bootstrap data envelopment analysis. Their results reveal that major banks are technically 
efficient more than their regional competitors within the time frame of the study. Their findings show a significant and positive association of board magnitude and committee meetings with bank efficiency. In line with agency theory and stewardship theory, the number of independent directors and board interaction has no significant impact on bank technical performance.

Furthermore, Detthamrong et al. (2017) also examine the governance mechanism and its influence on performance for a panel data sample of 493 firms of non-financial firms in Thailand during the period of 2001-2004. The study validates that on an average, firm's corporate governance variables such as board size, board independence, audit committee size, female directorship, CEO duality, and ownership concentration and audit reputation have no linear relationship with leverage and firm's performance. Furthermore, Ducassy and Guyot (2017) explore the complexity of ownership structure and corporate governance and its influence on firm performance in the French context. The study finds that control contestability level is essential in comprehending governance mechanisms.

Madanoglu et al. (2018) defend the perspective that the implementation of corporate governance requirements does not infer any detrimental effect on financial performance focusing on United States restaurant firms. Adopting Quantitative Comparative Analysis, the study reveals that three prominent governance provisions lead to superior financial performance. Paniagua et al. (2018) expands the prior studies by exploring the role of ownership and board structure on firm performance. The study finds an inverse relationship between Return on Equity and board members, which implies that a larger board size tends to reduce the profitability of the firm. In addition, the study suggests that dispersion of ownership has an inverse relationship with the Return on Equity, which reiterates that more payout reduces the firms' Return on Equity. To examine the influence of female directorship on firm performance, Green and Homroy (2018) explore whether gender diversity on corporate boards has a negative influence on the firm profitability in large European firms. The study finds that the influence of female representation on board committees is meaningful economically while the effect is modest on performance.

Ciftci et al. (2019) explore the importance of corporate governance structure on firm performance in the Turkey context. The study suggests that intensive ownership concentrations often when families are involved tend to positively contribute to better firm performance. Thus, the family's ownership tends to bear any risk of poor performance. In furtherance of corporate governance structure and firm performance, Mertzanisa et al. (2019) incorporate the effect of a social institution and firm-specific corporate governance and its effect on firm performance in MENA countries. The study avers the robust indicators of corporate governance such as board size and insider and ownership characteristics on firm performance, which identify the investors' awareness of the importance of corporate governance and firm performance.

Majority of the studies on corporate governance and firm performance explore the different governance characteristics, which could undermine the holistically view of the corporate governance structure. In addition, the introduction of diverse corporate governance proxies could increase explanatory power but might constitute statistical inconsistency (Tarchouna et al. 2017a). The statistical problems that is multicollinearity issues could occur due to complementarily interaction between corporate governance measurements (Ameziane Lasfer 2006, Florackis 2006). Consequently, the complementary relations amidst the corporate governance proxies could overload the model, which influence its reliability and limit researchers' conclusion. Thus, the multicollinearity problem is overcome by the construction of a single mechanism that depicts the overall corporate governance structure, which this study explores.

\subsection{Hypotheses developments}

$\mathrm{Ho}_{1}$ : Overall corporate governance does not contribute to Return on Asset in Nigeria.

$\mathrm{Ho}_{2}$ : Condensed corporate governance construct does not contribute to Return on Equity in Nigeria.

\section{Methodology}

\subsection{Data}

The study sort data mainly from the annual reports of the selected firms. The population of this study consists of the fifty-seven (57) listed financial institutions on the Nigerian stock exchange. However, the purposive sampling technique is adopted due to the irregularities of some firms' financial statements within the time frame of the study. Therefore, this study draws a sample of twenty-four (24) financial companies from the listed financial institutions in Nigeria for the period of 2013-2017. The sample size consists of twelve (12) Deposit Money Bank, one (1) mortgage bank and eleven (11) insurance companies. The significance of this period tends towards the post-financial crisis of financial institutions globally and Nigeria in which appropriate legislation and regulations emerge.

\subsection{Principal Component Analysis (PCA)}

This study adopts Principal Component Analysis to construct the condensed corporate governance indicator as to the major explanatory variables. The PCA reduces the extent of dimensionality of the loop of corporate governance measures that is interrelated but retains the most 
possible variable identified in the data set (Adams and Veprauskait 2013, Manuel et al. 2015, Tarchouna et al. 2017b). Interestingly, a new set of variables that is principal component is transformed by retaining a few principal components in the initial variables depicting the corporate governance constructs. Similarly, the benefits of PCA are attributed to its functionality to aggregate diverse constructs of corporate governance into a reduced indicator and elimination of multicollinearity that occurs in the instance of using diverse corporate governance proxies separately in same regression (Agrawal and Knoeber 1996). In addition, PCA attributes weights automatically to individual corporate governance proxies.

Notably, the validity of PCA depends on Bartlett's sphericity and Kaiser-Meyer-Olkin statistical test to adopt PCA method in this study. Accordingly, the null hypothesis of Bartlett's test assumes the correlation matrix is not factorable when linking the identity matrix and correlation matrix (Pett et al. 2003). The PCA is appropriate for factor analysis when the p-value of Bartlett's test for sphericity is less than 0.05 significant level. In addition, the second statistical test for PCA that is Kaiser-Meyer-Olkin for sampling adequacy, ranging from 0 to 1 , and the acceptable benchmark is 0.5 (Florackis and Ozkan 2009a). Therefore, the statistical outcome above 0.5 is satisfactorily for the study.

\subsection{Panel data estimators}

To evaluate the effect of the corporate governance system and firms' characteristics on firm performance, this study adopts the static panel estimators namely Ordinary Least Method (OLS), Fixed Method and Random Effect Method. The OLS model eliminates the panel structure of a dataset by pooling together the construct on the variables. However, the difference in coefficients is disregarded and eliminate possible heterogeneity. Prior studies suggest that the underlining assumptions are unrealistic (Detthamrong et al. 2017). Meanwhile, fixed effect and random effects are more suitable for static time series and cross-section dataset. The error term of the fixed effect specification assumes a constant variance over time and serially uncorrelated while the random effect specification controls for heterogeneity (Boudriga et al. 2010). Hausman test is then applied to select the most suitable estimators between fixed and random effects.

\subsection{Model specification}

This study adopts panel data for the analysis. Panel data is generally known as longitudinal or cross-sectional timeseries data, which observe firms' characteristics across the years. To test the formulated hypotheses, which assume the consequence of overall corporate governance on the performance of the firm are shown in the following econometric equations:

$$
\begin{aligned}
& R O A_{i t}=\beta_{0}+\beta_{1} \text { Index }_{i t}+\beta_{2} \operatorname{Tan}_{i t}+\beta_{3} \text { Own }_{i t}+ \\
& \beta_{4} \text { Size }_{i t}+\beta_{5} \text { Age }_{i t}+\beta_{6} \text { Lev }_{i t}+\varepsilon_{i t} ; \\
& R O E_{i t}=\beta_{0}+\beta_{1} \text { Index }_{i t}+\beta_{2} \operatorname{Tan}_{i t}+\beta_{3} O w n_{i t}+ \\
& \beta_{4} \text { Size }_{i t}+\beta_{5} \text { Age }_{i t}+\beta_{6} \text { Lev }_{i t}+\varepsilon_{i t} .
\end{aligned}
$$

The terms are defined in the Appendix. Where subscript $i$ presents the firms $(I=1 \ldots 24)$ while the subscript $t$ denotes the year $(t=2013 \ldots 2017)$.

\subsubsection{Dependent variables}

The firm performance is measured by the accounting indicators that is Return on Asset while the shareholder-value based measure that is Return on Equity. The Return on Asset is the periodic earnings relative to the total asset used to generate operating cash flow. Meanwhile, Return on Equity also a profitability measurement denotes the return on investment by determining the level of efficiency the company manage the shareholder funds (Adams and Veprauskait 2013).

\subsubsection{Independent variable}

The central explanatory variable of the study is the condensed corporate governance indicator. This study employs the principal component analysis (PCA) to condense six (6) corporate governance constructs namely the board magnitude, board engagement, board independence, degree of share held by directors, board insider and board committee. This method then allocates weight to individual corporate governance constructs, which eliminate multicollinearity problem and produce more reliable constructs than individual corporate governance indices (Larcker et al. 2007). The board insiders who are simultaneously involved in the daily routine of the firms while on the board too. Prior studies emphasis on the importance of the executive members, which tend to provide expertise skill and encourage better communication channel within the management (Ciftci et al. 2019). According to Zagorchev and Gao (2015), board committee takes the total number of the actuality of an audit committee, nomination committee, governance committee, and nomination committee. The importance of board committee is emphasized by a global code of corporate governance such as the Sarbanes-Oxley Act of 2002, as the existence of the committees depict good governance. We expect the overall corporate governance measures to mitigate any information asymmetric, conflict of interest and promote the shareholders' values by achieving the overall objectives of the firm. 


\section{Empirical findings}

\subsection{Descriptive statistics}

Table 1 presents the descriptive figures of both the explained variables and exploratory variables used in this study to describe the trend and spread of the dataset. The table accounts for the total observations, the mean, standard deviation, minimum and maximum figures for each dataset.

From Table 1, the mean of the ROA is $4.35 \%$, which ranges between the minimum values of $-25.7 \%$ and the maximum value of $55.4 \%$. This indicates the level of periodic earnings to total asset capable of generating cash flows. The standard deviation of 0.0769 indicates that most sampled firms maintain an average return on asset. In addition, the mean Return of Equity is $14 \%$ and its minimum value takes -0.58 while the maximum value of 1.428 signifying the extent at which the shareholder's fund is employed efficiently.

In respect to the corporate governance, the mean of board magnitude is approximately 12 persons with a maximum value of 20 persons on the board and minimum of 5 persons. The degree of an independent director on average is $11.2 \%$ with none at the minimum and the maximum value of $33.3 \%$ of the total board magnitude. The firms also have on average 4 board committee but 2 board committee at the minimum and 7 board committee at the maximum. The degree of shares held by the directors is averagely $17 \%$, with a minimum value of less than $1 \%$ and maximum value tends to $100 \%$. In addition, the percentage number of executive directors on the board is averagely $28 \%$, with a minimum value of $8 \%$ and $50 \%$ maximum value. The average number of board engagement is approximately 6 times with minimum meeting held is 3 and a maximum of 12 .

\subsection{Condensed corporate governance proxy using PCA}

This study adopts six corporate governance variables identified by prior literature such as Board Magnitude, Independent Director, Board Interactions, Director Ownership, Board Insider and Board Committee. These constructs are condensed into a unique corporate governance index by PCA. In operationalizing PCA, the study selects the first principal component, which represents the largest percentage variance in the initial dataset aligning with Ellul and Yerramilli (2013), Florackis and Ozkan (2009a), Tarchouna et al. (2017a).

Table 2 presents the outcome of Principal Component Analysis for the adopted corporate governance variables. The Panel (A) of Table reports the correlation matrix of the six corporate governance proxies attributable to the overall

Table 1. Descriptive statistics of the used variables (source: authors' computation)

\begin{tabular}{|c|c|c|c|c|c|}
\hline VARIABLES & $\mathrm{N}$ & Mean & Standard Deviation & Minimum & Maximum \\
\hline \multicolumn{6}{|l|}{ Firm Performance } \\
\hline ROA & 120 & 0.0435 & 0.0769 & -0.257 & 0.554 \\
\hline $\mathrm{ROE}$ & 120 & 0.140 & 0.232 & -0.580 & 1.428 \\
\hline \multicolumn{6}{|c|}{ Corporate Governance } \\
\hline BS & 120 & 11.72 & 3.883 & 5 & 20 \\
\hline $\mathrm{BIN}$ & 120 & 0.112 & 0.0837 & 0 & 0.333 \\
\hline $\mathrm{BC}$ & 120 & 4.142 & 1.245 & 2 & 7 \\
\hline $\mathrm{DOH}$ & 120 & 0.167 & 0.256 & 0.0004 & 0.991 \\
\hline BI & 120 & 0.281 & 0.114 & 0.0833 & 0.500 \\
\hline $\mathrm{BM}$ & 120 & 5.517 & 1.796 & 3 & 12 \\
\hline \multicolumn{6}{|c|}{ Firms Characteristics } \\
\hline Size & 120 & 18.37 & 2.121 & 14.24 & 21.98 \\
\hline Own & 120 & 0.448 & 0.308 & 0.0550 & 0.999 \\
\hline Lev & 120 & 0.536 & 0.312 & 0.00122 & 0.926 \\
\hline Tan & 120 & 0.0690 & 0.0967 & $7.45 \mathrm{e}-05$ & 0.482 \\
\hline Age & 120 & 1.060 & 0.447 & 0 & 3.305 \\
\hline
\end{tabular}

Note: The variables are defined as follows: Return on Asset (ROA) is the ratio of profit before tax to total assets; Return on Equity (ROE) is measured as the ratio of profit before tax to equity; Board magnitude (BS) is the total board members; Board Independent $(\mathrm{BIN})$ is the ratio of independent director to total board; Board Meeting (BM) is the number of meetings held yearly; Board Ownership $(\mathrm{DOH})$ is the percentage of number of shares held by directors to total shares; Board activeness (BI) is the ratio of executive directors to board magnitude; Board Committee (BC) is the number of Board Committees; Firm Tangibility (Tan) is the ratio of total fixed assets to total assets; Shareholding (Own) is the ratio of shareholders' fund to total assets; Firm size (Size) - Natural logarithm of total asset; Firm Age (Age) is the natural logarithm of number of years listed; Leverage (Lev) is the ratio of total debt to total assets. 
Table 2. Principal component analysis for adopted corporate governance variables (source: author's computation)

\begin{tabular}{|c|c|c|c|c|c|c|}
\hline & 1 & 2 & 3 & 4 & 5 & 6 \\
\hline \multicolumn{7}{|l|}{ Panel (A): Correlation Matrix } \\
\hline 1. Board Magnitude & 1 & & & & & \\
\hline 2. Independent Director & -0.0893 & 1 & & & & \\
\hline 3. Board Interactions & $0.410^{* * *}$ & $0.185^{*}$ & 1 & & & \\
\hline 4. Director Ownership & -0.168 & 0.133 & $0.232^{*}$ & 1 & & \\
\hline 5. Board Insider & $0.548^{* * *}$ & 0.151 & $0.493^{* * *}$ & -0.131 & 1 & \\
\hline 6. Board Committee & $0.293^{* *}$ & -0.107 & $0.188^{*}$ & -0.0983 & 0.142 & 1 \\
\hline \multicolumn{7}{|c|}{ Panel (B): Principal Component Weight } \\
\hline Index & 0.557 & 0.0816 & 0.309 & -0.0617 & 0.5657 & 0.5143 \\
\hline \multicolumn{7}{|c|}{ Panel (C): Validity of Principal Component Analysis } \\
\hline Bartlett test of sphericity (p-value) & 0.000 & & & & & \\
\hline Kaiser-Meyer-Olkin & 0.593 & & & & & \\
\hline
\end{tabular}

${ }^{*} p<0.05,{ }^{* *} p<0.01,{ }^{* * *} p<0.001$.

corporate governance index. The correlation coefficients are weak, which depict that the variables capture different features of the corporate governance system (Adams and Veprauskait 2013, Tarchouna et al. 2017a).

In addition, Panel (B) indicates the weights of the first principal components, which is highly characterized by Board Magnitude, Board Insider and Board Committee as the absolute value of the factor loading is greater than 0.5. This signifies the positive contributions to the overall corporate governance system. Based on the result of the positive contribution of the board magnitude, following Dalton et al. (1999), this suggests that large board composition enables the firm to attract more expertise skills and available resources. Furthermore, the Board Committees contribute positively to the overall corporate governance system, which depicts the essence of board committees as Nigerian Code of Corporate Governance 2011 prioritizes the committees for good governance. Board Insider with its positive contribution could suggest bad governance as it tends to compromise the board independence following the finding of Yermack (1996), Larcker et al. (2007).

Additionally, Panel (C) of the Table presents the validity of the PCA. The null of Bartlett's test of equal correlation matrix with the identity matrix is rejected with a p-value of 0.000 . This result identifies the linear correlation exists between the variables. In addition, the Kaiser-Meyer-Olkin test reports a statistic approximately 0.6 greater than 0.5 , which is the benchmark (Florackis and Ozkan 2009a, Tarchouna et al. 2017a). This suggests that the condensed proxy represents the six (6) adopted corporate governance constructs adequately (Stewart 1981). Therefore, the conformity with the above statistic test validates the satisfactory adoption of PCA in this study.

\subsection{Regression analysis results}

This section presents the empirical result of the study regarding the overall corporate governance system on financial performance. Table 3 reports the OLS, fixed effect and random effect regression where the explained variable is Return on Asset (ROA). However, due to the limitation of OLS regression in financial performance studies, the emphasis of the study is based on the fixed effect and random effect regression.

\subsubsection{Effect of condensed corporate governance measure on return on asset}

Panel A of Table 3 shows the effect of the condensed corporate governance constructs on the Return on Asset for the overall sample. Moreover, the fixed effect and random effect regression are presented in Panel A, the Hausman test suggests that fixed effect regression is more appropriate for inference of the result at a $\mathrm{p}$-value of 0.002 with $\mathrm{R}^{2}=0.229$. This means that encompassing both control variables and the constructed index explain $23 \%$ of the Return on Asset. The result infers that the effect of the condensed corporate governance construct is significantly negative on the Return on Asset at 0.05 level of significance. In economic magnitude, this result suggests that the increase in the condensed corporate governance construct will decrease the level of Return on Asset in economic magnitude. Better governance results in a higher return on asset, nevertheless the results indicate that weaker governance of financial institutions in Nigeria undermines the accounting profit that is Return on Asset. This weak governance can be traced to the weak institution saddled with the responsibility to implement globally accepted corporate governance measures. This result is in conformity with the study of Love and Rachinsky (2015) in Russia (but not significant). 
Table 3. Empirical result: return on asset as explained variable (source: author's computation)

\begin{tabular}{|c|c|c|c|c|c|c|c|c|c|}
\hline & \multicolumn{3}{|c|}{ Panel A: Overall Sample } & \multicolumn{3}{|c|}{ Panel B: Deposit Money Bank } & \multicolumn{3}{|c|}{ Panel C: Other Financial Institutions } \\
\hline & OLS & Fixed & Random & OLS & Fixed & Random & OLS & Fixed & Random \\
\hline \multirow{2}{*}{ Index } & $-0.0308^{\star * *}$ & $-0.0397^{\star *}$ & $-0.0259^{\star *}$ & $-0.0498^{* * *}$ & $-0.0255^{\star}$ & $-0.0371^{\star *}$ & -0.0189 & -0.0413 & -0.0174 \\
\hline & $(0.00914)$ & $(0.0162)$ & $(0.0120)$ & $(0.0163)$ & $(0.0147)$ & $(0.0164)$ & $(0.0158)$ & $(0.0260)$ & $(0.0197)$ \\
\hline \multicolumn{10}{|c|}{ Control Variable } \\
\hline \multirow{2}{*}{ Tan } & $-0.340^{* * *}$ & 0.0786 & $-0.262^{\star \star}$ & 0.869 & $-4.874^{\star * *}$ & -0.0351 & $-0.439^{\star * *}$ & 0.0929 & $-0.260^{*}$ \\
\hline & $(0.0700)$ & $(0.180)$ & $(0.105)$ & $(0.556)$ & $(1.181)$ & $(0.655)$ & $(0.0980)$ & $(0.217)$ & $(0.138)$ \\
\hline \multirow{2}{*}{ Own } & 0.0286 & -0.0341 & 0.00837 & 0.0581 & -0.0400 & 0.0200 & & & \\
\hline & $(0.0567)$ & $(0.0672)$ & $(0.0620)$ & $(0.0400)$ & $(0.0458)$ & $(0.0422)$ & & & \\
\hline \multirow{2}{*}{ Size } & -0.00140 & $-0.0857^{\star * \star}$ & -0.00580 & 0.00353 & -0.00820 & 0.00405 & $-0.0458^{\star \star}$ & $-0.115^{\star * *}$ & $-0.0756^{* * *}$ \\
\hline & $(0.00442)$ & $(0.0190)$ & $(0.00647)$ & $(0.00385)$ & $(0.0367)$ & $(0.00516)$ & $(0.0202)$ & $(0.0248)$ & $(0.0215)$ \\
\hline \multirow{2}{*}{ Age } & -0.0165 & -0.00264 & -0.0121 & -0.0169 & $-0.114^{\star * *}$ & -0.0200 & -0.0329 & 0.00476 & -0.00202 \\
\hline & $(0.0159)$ & $(0.0207)$ & $(0.0186)$ & $(0.0214)$ & $(0.0348)$ & $(0.0248)$ & $(0.0262)$ & $(0.0265)$ & $(0.0260)$ \\
\hline \multirow{2}{*}{ Lev } & 0.0254 & 0.145 & 0.00813 & 0.0619 & -0.000835 & 0.0227 & 0.0580 & -635.3 & 0.146 \\
\hline & $(0.0542)$ & $(0.153)$ & $(0.0646)$ & $(0.0397)$ & $(0.182)$ & $(0.0435)$ & $(0.0653)$ & $(1,688)$ & $(0.0971)$ \\
\hline \multirow{2}{*}{ Constant } & 0.0838 & $1.552^{\star * *}$ & 0.173 & -0.0661 & 0.483 & -0.0199 & $0.861^{\star *}$ & $1.632^{\star * *}$ & $1.262^{\star * \star}$ \\
\hline & $(0.105)$ & $(0.337)$ & $(0.139)$ & $(0.0866)$ & $(0.771)$ & $(0.108)$ & $(0.330)$ & $(0.361)$ & $(0.344)$ \\
\hline $\begin{array}{l}\text { Obser- } \\
\text { vations }\end{array}$ & 120 & 120 & 120 & 60 & 60 & 60 & 60 & 60 & 60 \\
\hline R-squared & 0.268 & 0.229 & & 0.347 & 0.435 & & 0.330 & 0.369 & \\
\hline F-test & 6.901 & 4.449 & 15.28 & 4.696 & 5.382 & 16.19 & 5.317 & 4.086 & 17.33 \\
\hline Prob $>$ F & $2.91 \mathrm{e}-06$ & 0.000549 & 0.0182 & 0.000671 & 0.000338 & 0.0128 & 0.000481 & 0.00257 & 0.00391 \\
\hline $\begin{array}{l}\text { Hausman } \\
\text { Test }\end{array}$ & & 26.7 & & & 39.90 & & & & 5.21 \\
\hline $\mathrm{p}$-value & & 0.0002 & & & 0.0000 & & & & 0.0740 \\
\hline
\end{tabular}

Standard errors in parentheses: ${ }^{* *} p<0.01,{ }^{* *} p<0.05,{ }^{\star} p<0$. The variables are defined as follows: Return on Asset (ROA) is the ratio of profit before tax to total assets; Return on Equity (ROE) is measured as the ratio of profit before tax to equity; Board magnitude (BS) is the total board members; Board Independent (BIN) is the ratio of independent director to total board; Board Meeting (BM) is the number of meetings held yearly; Board Ownership (DOH) is the percentage of number of shares held by directors to total shares; Board activeness (BI) is the ratio of executive directors to board magnitude; Board Committee (BC) is the number of Board Committees; Firm Tangibility (Tan) is the ratio of total fixed assets to total assets; Shareholding (Own) is the ratio of shareholders' fund to total assets; Firm size (Size) - Natural logarithm of total asset; Firm Age (Age) is the natural logarithm of number of years listed; Leverage (Lev) is the ratio of total debt to total assets.

Furthermore, the overall sample is then discomposed into two subsamples namely Panel B deals with the Deposit Money Banks and Panel C of Table 3 reflects the other financial institutions. Similar to the overall sample result, the effect of the condensed corporate governance construct on the Return on Asset is negative and significant at 0.1 level of significance. This result suggests the percentage increase in the condensed corporate governance mechanism will lead to a decrease in Return on Asset. This reflects also weak governance exhibited by the Money Deposit Banks in Nigeria.

Panel C of Table 3 infers the effect of condensed corporate governance measure on the Return on Asset in other financial institutions, which include the mortgage bank and the insurance companies. Following the Hausman test estimate, the test suggests random effect regression for the analysis at a p-value of 0.0740 . This result infers a negative but not significant effect of the corporate governance index on Return on Asset. This result is in conformity with the prior study of Love and Rachinsky (2015) in Russia.

\subsubsection{Effect of condensed corporate governance measure on return on equity}

Following the second hypotheses of this study, Table 4 reports the effect of the condensed corporate governance mechanism on the Return on Equity. Panel A of Table 4 reflects the position of the corporate governance index on the Return on Equity for the overall sample. The Hausman test suggests that the fixed effect regression is appropriate at a $\mathrm{p}$-value of 0.0061 with $\mathrm{R}^{2}=0.158$. This means that encompassing both control variables and the constructed 
index explain 16\% of the Return on Equity. The result suggests an insignificant and negative influence of corporate governance index on Return on Equity. This result is inconsistent with the study of Love and Rachinsky (2015) in Russia (however, insignificant).

Panel B of Table 4 infers the influence of the corporate governance index on Return on Equity for the Money Deposit Banks. With the report of the Hausman test, the random effect is more appropriate for the result inference at a p-value of 0.1526 . The result, however, suggests a significant and negative effect of corporate governance index on financial performance (Return on Equity). This result in economic magnitude reports an increase in corporate governance index will decrease the level of Return on Equity.

Furthermore, Panel C of Table 4 reports the effect of condensed corporate governance measure on Return on Equity among other financial institutions. With the
Hausman test result, the random effect regression is more appropriate at a p-value of 0.5658 . The result suggests a negative but not significant effect of condensed corporate governance measure on the Return on Equity. This result is inconsistent with the study of Love and Rachinsky (2015) in Russia (however, insignificant).

\section{Discussion of the findings}

In building the corporate governance index, six (6) corporate governance mechanisms are condensed using the Principal Component Analysis. As mention earlier, the corporate governance mechanisms include board magnitude, board engagement, board independence, board insider, director ownership and board committees as identified by prior studies. The principal component analysis allocates weights to individual corporate governance measures in

Table 4. Empirical result: return on equity as explained variable (source: author's computation)

\begin{tabular}{|c|c|c|c|c|c|c|c|c|c|}
\hline & \multicolumn{3}{|c|}{ Panel A: Overall Sample } & \multicolumn{3}{|c|}{ Panel B: Deposit Money Bank } & \multicolumn{3}{|c|}{ Panel C: Other Financial Institutions } \\
\hline & OLS & Fixed & Random & OLS & Fixed & Random & OLS & Fixed & Random \\
\hline \multirow[t]{2}{*}{ Index } & $-0.0818^{\star * *}$ & -0.0504 & $-0.0590^{*}$ & -0.0489 & -0.0140 & $-0.0371^{\star *}$ & -0.0538 & -0.0711 & -0.0279 \\
\hline & $(0.0276)$ & $(0.0532)$ & $(0.0352)$ & $(0.0333)$ & $(0.0215)$ & $(0.0164)$ & $(0.0527)$ & $(0.101)$ & $(0.0648)$ \\
\hline \multicolumn{10}{|c|}{ Control Variable } \\
\hline \multirow[t]{2}{*}{ Tan } & $-0.850^{* * *}$ & -0.0510 & $-0.717^{\star *}$ & 0.817 & $-7.226^{* * *}$ & -0.0351 & $-0.992^{\star * *}$ & -0.160 & $-0.774^{\star}$ \\
\hline & $(0.211)$ & $(0.593)$ & $(0.295)$ & $(1.136)$ & $(1.725)$ & $(0.655)$ & $(0.327)$ & $(0.838)$ & $(0.436)$ \\
\hline \multirow[t]{2}{*}{ Own } & -0.0778 & -0.244 & -0.0892 & 0.0117 & $-0.128^{\star}$ & 0.0200 & & & \\
\hline & $(0.171)$ & $(0.221)$ & $(0.189)$ & $(0.0817)$ & $(0.0668)$ & $(0.0422)$ & & & \\
\hline \multirow[t]{2}{*}{ Size } & -0.00369 & $-0.232^{\star * \star}$ & -0.0149 & -0.00278 & -0.0414 & 0.00405 & -0.0829 & $-0.311^{\star * *}$ & $-0.153^{\star *}$ \\
\hline & $(0.0133)$ & $(0.0626)$ & $(0.0182)$ & $(0.00787)$ & $(0.0536)$ & $(0.00516)$ & $(0.0674)$ & $(0.0961)$ & $(0.0744)$ \\
\hline \multirow[t]{2}{*}{ Age } & -0.0243 & -0.00926 & -0.0246 & -0.0205 & $-0.159^{\star * *}$ & -0.0200 & -0.0710 & -0.00257 & -0.0260 \\
\hline & $(0.0480)$ & $(0.0682)$ & $(0.0558)$ & $(0.0438)$ & $(0.0508)$ & $(0.0248)$ & $(0.0874)$ & $(0.103)$ & $(0.0921)$ \\
\hline \multirow[t]{2}{*}{ Lev } & 0.201 & $1.273^{\star *}$ & 0.210 & $0.190^{* *}$ & 0.182 & 0.0227 & $0.553^{\star *}$ & $-2,937$ & $0.786^{* * *}$ \\
\hline & $(0.164)$ & $(0.503)$ & $(0.192)$ & $(0.0811)$ & $(0.266)$ & $(0.0435)$ & $(0.218)$ & $(6,538)$ & $(0.298)$ \\
\hline \multirow[t]{2}{*}{ Constant } & 0.219 & $3.839^{* * *}$ & 0.417 & 0.0949 & 1.267 & -0.0199 & 1.411 & 2,943 & $2.409^{\star *}$ \\
\hline & $(0.317)$ & $(1.108)$ & $(0.401)$ & $(0.177)$ & $(1.126)$ & $(0.108)$ & $(1.101)$ & $(6,538)$ & (1.199) \\
\hline Observations & 120 & 120 & 120 & 60 & 60 & 60 & 60 & 60 & 60 \\
\hline R-squared & 0.262 & 0.158 & & 0.284 & 0.383 & & 0.293 & 0.225 & \\
\hline F-test & 6.691 & 2.814 & 17.29 & 3.509 & 4.340 & 16.19 & 4.477 & 2.036 & 12.61 \\
\hline Prob $>F$ & $4.42 \mathrm{e}-06$ & 0.0148 & 0.00826 & 0.00537 & 0.00171 & 0.0128 & 0.00174 & 0.0820 & 0.0273 \\
\hline Hausman Test & & 18.05 & & & & 9.39 & & & 1.14 \\
\hline p-value & & 0.0061 & & & & 0.1526 & & & 0.5658 \\
\hline
\end{tabular}

Standard errors in parentheses: ${ }^{* *} p<0.01,{ }^{* *} p<0.05,{ }^{*} p<0$. The variables are defined as follows: Return on Asset (ROA) is the ratio of profit before tax to total assets; Return on Equity (ROE) is measured as the ratio of profit before tax to equity; Board magnitude (BS) is the total board members; Board Independent (BIN) is the ratio of independent director to total board; Board Meeting (BM) is the number of meetings held yearly; Board Ownership (DOH) is the percentage of number of shares held by directors to total shares; Board activeness (BI) is the ratio of executive directors to board magnitude; Board Committee (BC) is the number of Board Committees; Firm Tangibility (Tan) is the ratio of total fixed assets to total assets; Shareholding (Own) is the ratio of shareholders' fund to total assets; Firm size (Size) - Natural logarithm of total asset; Firm Age (Age) is the natural logarithm of number of years listed; Leverage (Lev) is the ratio of total debt to total assets. 
which the analysis identifies the positive contribution of the board magnitude, Board Insider and Board Committees to the overall corporate governance index (see Table 3).

The findings are summarized henceforth. First, the overall corporate governance is associated with firm performance. However, the level of association is negative, which contrary to the prior studies such as Love and Rachinsky (2015) in Ukraine, Zagorchev and Gao (2015) in U.S. financial institutions, whose results indicate a significantly positive association between corporate governance index and firm performance. Better governance expected to result in a higher return on asset, nevertheless our findings indicate that Nigerian financial institutions are characterized by weaker governance, which undermines the firms' performance. This weak governance can be traced to the weak institution saddled with the responsibility to implement globally accepted corporate governance measures, which aligns with (Adegbite 2015b).

Similarly, following the extent of the board magnitude, board insider and board committee contribution to the overall corporate governance index, this study suggests that large board magnitude could undermine the financial performance of the firms. This is consistent with prior studies such as Yermack (1996) for 452 U.S large firms; Eisenberg, Sundgren and Wells (1998), and Grove et al. (2011) whose results reflect the negative relationship of board size with the firm performance. These findings propose that the increase in board size tends to deteriorate firm performance. This implies that a larger board constitutes ineffective communication channel between the board, poor decision, and difficulty on coordination (Detthamrong et al. 2017). Therefore, the ability to restructure the larger board magnitude could improve the firm performance. In addition, the extent of the contribution of the magnitude of the board committee is positive following the result of PCA. However, this could erode the performance of the firm. In conformity of Jiraporn et al. (2009) study, the board committees could be restricted to the proponent committee such as audit; risk; nominating and remuneration committee instead of an unnecessary extension.

\section{Conclusions}

The study explores the effect of condensed corporate governance construct on firm performance while controlling for firms' characteristics in the listed financial institutions in Nigeria. This study samples twenty-four (24) listed financial institutions in Nigeria. The paper then constructs the corporate governance index using six (6) corporate governance mechanisms with Principal Component Analysis. The formulated hypothesis is tested by employing static panel data estimators that are Fixed effect and Random Effect Regression.
Prior research especially from developed economies provides useful insight on the effect of corporate governance index on firm performance. However, the scenario of developing economies tends to vary as they are surrounded by weak institutions. Therefore, this paper examines the level of influence of overall corporate governance structure on the performance of firms in developing the economy, especially in Nigeria, to provide additional insights that could help practitioners and regulators.

The results reveal that while controlling for firms' characteristics, constructed corporate governance indicator has a significant and negative influence on the firm performance measured by Return on Asset and Return on Equity. This finding supports that larger board, larger board committees and significant executive involvement have a detrimental influence on the performance of firms. The result implies a weak corporate governance structure is detrimental to higher financial performance amidst the weak institutions characterized in Nigeria context. That is, weaker corporate governance exhibits lower financial performance. Therefore, the key perception of this study is that the voluntary corporate governance measures adopted by financial institutions are ineffectively characterized by a weak environment like Nigeria. However, we believe that the adoption of voluntary corporate governance measures could be effectively provided the political and legal institutions are effective introgressively.

This study then recommends that the corporate governance structure in Nigeria listed firms should be review with the intention to enhance the firm performance. Further, it encourages the regulatory agencies like Central Bank of Nigeria, National Insurance Commission, and the Securities and Exchange Commission, to monitor the compliance of the listed firms to good governance behaviour. This study encompasses limitations. This study then encourages future research to incorporate more corporate governance mechanisms in building the corporate governance index and extend the number of study time frame.

\section{Author contributions}

Adegboye Alex, Ebuzor Emmanuel and SAMSON Dayo were responsible for the design and development of the data analysis and were responsible for data collection and analysis. While Ojeka Stephen and Adegboye Amos conceived the study and responsible for data interpretation and conclusion.

\section{Disclosure statement}

The authors of the study do not have any competing financial, professional or personal interests from other parties. 


\section{Reference}

Adams M, Veprauskait E (2013) Do powerful chief executives influence the financial performance of UK firms? The British Accounting Review 45 (3): 229-241. https://doi.org/10.1016/j.bar.2013.06.004

Adegbite E (2015a) Good corporate governance in Nigeria: Antecedents, propositions and peculiarities. International Business Review 24 (2): 319-330. https://doi.org/10.1016/j.ibusrev.2014.08.004

Adegbite E (2015b) Good corporate governance in Nigeria: Antecedents, propositions and peculiarities. International Business Review 24 (2): 319-330.

https://doi.org/10.1016/j.ibusrev.2014.08.004

Agrawal A, Knoeber C (1996) Firm performance and mechanisms to control agency problems between managers and shareholders. Journal of Financial and Quantitative Analysis 31 (3): 377-397. https://doi.org/10.2307/2331397

Akhigbe A, Martin AD (2008) Influence of disclosure and governance on risk of US financial services firms following Sarbanes-Oxley. Journal of Banking \& Finance 32: 2124-2135. https://doi.org/10.1016/j.jbankfin.2007.12.037

Ahmed E, Hamdan A (2015) The impact of corporate governance on firm performance: evidence from Bahrain stock exchange. European Journal of Business and Innovation Research 3 (5): 25-48.

Allen F, Fukuda Sichi, Hoshi T, Miyajima H (2018) Corporate governance: Editor's introduction. Journal of the Japanese and International Economies 47 (January): 1-2. https://doi.org/10.1016/j.jjie.2018.01.002

Ameziane Lasfer M (2006) The interrelationship between managerial ownership and board structure. Journal of Business Finance and Accounting 33 (7-8): 1006-1033. https://doi.org/10.1111/j.1468-5957.2006.00600.x

Ararat M, Black BS, Yurtoglu BB (2017) The effect of corporate governance on firm value and profitability: Time-series evidence from Turkey. Emerging Markets Review 30 (September 2015): 113-132. https://doi.org/10.1016/j.ememar.2016.10.001

Armstrong CS, Blouin JL, Jagolinzer AD, Larcker DF (2015) Corporate governance, incentives, and tax avoidance. Journal of Accounting and Economics 60 (1): 1-17. https://doi.org/10.1016/j.jacceco.2015.02.003

Bird RC, Borochin PA, Knopf JD (2015) The role of the chief legal officer in corporate governance. Journal of Corporate Finance 34: 1-22. https://doi.org/10.1016/j.jcorpfin.2015.07.002

Boudriga A, Taktak NB, Jellouli S (2010) Bank specific, business and institutional environment determinants of banks nonperforming loans: evidence from Mena countries. Research Gate.

Caprio G, Laeven L, Levine R (2007) Governance and bank valuation. Journal of Financial Intermediation 16: 584-617. Coles. https://doi.org/10.1016/j.jfi.2006.10.003

Ciftci I, Tatoglu E, Wood G, Demirbag M, Zaim S (2019) Corporate governance and firm performance in emerging markets: Evidence from Turkey. International Business Review 28 (1): 90-103. https://doi.org/10.1016/j.ibusrev.2018.08.004

Cornett MM, Mcnutt JJ, Tehranian H (2009) Corporate governance and earnings management at large U.S. bank holding companies. Journal of Corporate Finance 15 (4): 412-430. https://doi.org/10.1016/j.jcorpfin.2009.04.003

Detthamrong U, Chancharat N, Vithessonthi C (2017) Corporate governance, capital structure and firm performance: Evidence from Thailand. Research in International Business and Finance 42 (July): 689-709. https://doi.org/10.1016/j.ribaf.2017.07.011

Diamond DW, Rajan RG (2008) The credit Crisis: Conjenctures about causes and remedies (December), 606-610 pp. https://doi.org/10.3386/w14739

Ducassy I, Guyot A (2017) Complex ownership structures, corporate governance and firm performance: The French context. Research in International Business and Finance 39: 291-306. https://doi.org/10.1016/j.ribaf.2016.07.019

Eisenberg T, Sundgren S, Wells MT (1998) Large board size and decreasing firm value in small firms. Journal of Financial Economics 48: 35-54. https://doi.org/10.1016/S0304-405X(98)00003-8

Ellul A, Yerramilli V (2013) Stronger risk controls, lower risk: Evidence from U.S. bank holding companies. Journal of Finance 68 (5): 1757-1803. https://doi.org/10.1111/jofi.12057

Emile R, Ragab A, Kyaw A (2014) The effect of corporate governance on firm performance: Evidence from Egypt. Asian Economic and Financial Review 4 (12): 1865-1877. https:// doi.org/10.18488/journal.aefr/2014.4.12/102.12.1865.1877

Faleye O, Krishnan K (2010) Risky lending: does bank corporate governance matter? http://ssrn.com/abstract

Fama EF, Jensen MC (1983) Separation of ownership and control. Journal of Law and Economics 26: 301-324. https://doi.org/10.1086/467037

Flannery MJ, Kwan SH, Nimalendran M (2013) The 2007-2009 financial crisis and bank opaqueness. Journal of Financial Intermediation 22: 55-84. https://doi.org/10.1016/j.jfi.2012.08.001

Florackis C (2006) Internal corporate governance mechanisms and corporate performance: evidence for UK firms Internal corporate governance mechanisms and corporate performance: evidence for UK firms (January 2015): 37-41. https://doi.org/10.1080/17446540500143897

Florackis C, Ozkan A (2009a) Managerial incentives and corporate leverage: Evidence from the United Kingdom. Accounting and Finance 49 (3): 531-553. https://doi.org/10.1111/j.1467-629X.2009.00296.x

Florackis C, Ozkan A (2009b) The impact of managerial entrenchment on agency costs: An empirical investigation using UK panel data. European Financial Management 15 (3): 497-528. https://doi.org/10.1111/j.1468-036X.2007.00418.x

García-Meca E, García-Sánchez I-M, Martínez-Ferrero J (2014) Board diversity and its effects on bank performance: An international analysis. Journal of Banking \& Finance 53: 202-214. https://doi.org/10.1016/j.jbankfin.2014.12.002

Green CP, Homroy S (2018) Female directors, board committees and firm performance. European Economic Review 102: 1938. https://doi.org/10.1016/j.euroecorev.2017.12.003

Grove H, Patelli L, Victoravich LM, Xu PT (2011) Corporate governance and performance in the wake of the financial crisis: evidence from US commercial banks. Corporate Governance: An International Review 19 (5): 418-436. https://doi.org/10.1111/j.1467-8683.2011.00882.x 
Haan J De, Vlahu R (2012) Corporate governance of financial institutions. Annual Review of Financial Economics 4 (4): 215232. https://doi.org/10.1146/annurev-financial-110311-101821

Hopt KJ (2013) Better governance of financial institutions. Better Governance of Financial Institutions (April), 1-71 pp.

Huang X, Kang JK (2017a) Geographic concentration of institutions, corporate governance, and firm value. Journal of Corporate Finance 47: 191-218.

https://doi.org/10.1016/j.jcorpfin.2017.09.016

Huang X, Kang JK (2017b) Geographic concentration of institutions, corporate governance, and firm value. Journal of Corporate Finance 47: 191-218.

https://doi.org/10.1016/j.jcorpfin.2017.09.016

Jiraporn P, Kim JC, Kim YS (2011) Dividend payouts and corporate governance quality: An empirical investigation. Financial Review 46 (2): 251-279.

https://doi.org/10.1111/j.1540-6288.2011.00299.x

Jensen MC, Meckling W (1976) Theory of the firm' Managerial behavior, agency cost and ownership structure. Journal of Financial Economics 3: 305-360. https://doi.org/10.1016/0304-405X(76)90026-X

Khan H (2011). A literature review of corporate governance. International Conference on E-Business, Management and Economics 25: 1-5.

Lakshan AMI, Wijekoon WMHN (2012) Corporate governance and corporate failure. Procedia Economics and Finance 2 (Af): 191-198. https://doi.org/10.1016/S2212-5671(12)00079-2

Larcker DF, Richardson SA, Tuna I (2007) Corporate Governance, Accounting Outcomes, and Organizational Performance. The accounting Review 82 (4): 963-1008.

https://doi.org/10.2308/accr.2007.82.4.963

Lemmon ML, Lins KV (2003) Ownership structure, corporate governance, and firm value: Evidence from the East Asian financial crisis. Journal of Finance 58: 1445-1468. https://doi.org/10.1111/1540-6261.00573

Love I, Rachinsky A (2015) Corporate governance and bank performance in emerging markets: evidence from Russia and Ukraine. Emerging Markets Finance \& Trade (July 2015). https://doi.org/10.1080/1540496X.2014.998945

Madanoglu M, Kizildag M, Ozdemir O (2018) Which bundles of corporate governance provisions lead to high firm performance among restaurant firms? International Journal of Hospitality Management 72 (January): 98-108. https://doi.org/10.1016/j.ijhm.2018.01.006

Manuel A, David O, Schmid M (2015) Frage - Antwort vertebragene bauchschmerzen. Journal of Empirical Finance 184 (4): 646. https://doi.org/10.1016/j.jemp

Matei A, Drumasu C (2015) Corporate governance and public sector entities. Procedia Economics and Finance 26 (15): 495 504. https://doi.org/10.1016/S2212-5671(15)00879-5

Mertzanisa C, Basuonyb M, Mohamed E (2019) Social institutions, corporate governance and firm-performance in the MENA region. Research in International Business and Finance 48: 75-96. https://doi.org/10.1016/j.ribaf.2018.12.005

Munisi G, Randøy T (2013) Corporate governance and company performance across Sub-Saharan African countries. Journal of Economics and Business 70: 92-110.

https://doi.org/10.1016/j.jeconbus.2013.08.003
Ojeka SA, Adegboye A, Adegboye K, Alabi O, Afolabi M, Iyoha F (2019) Chief financial officer roles and enterprise risk management: An empirical based study. Heliyon 5 (6): e01934. https://doi.org/10.1016/j.heliyon.2019.e01934

Ojeka S, Adegboye A, Titilayo Adetula D, Adegboye K, Udoh I (2019) IFRS adoption and CEO compensation: evidence from listed banks in Nigeria. Banks and Bank Systems 14 (3): 1-8. https://doi.org/10.21511/bbs.14(3).2019.01

Ojeka SA, Fakile SA, Anijesu A, Owolabi I (2017) Examining the Quality of financial reporting in the banking sector in Nigeria: does audit committee accounting expertise matter? Journal of Internet Banking and Commerce 21 (3): 1-18.

Paniagua J, Rivelles R, Sapena J (2018) Corporate governance and financial performance: The role of ownership and board structure. Journal of Business Research 89 (January): 229-234. https://doi.org/10.1016/j.jbusres.2018.01.060

Pett MA, Lackey NR, Sullivan JJ (2003) Making sense of factor analysis: The use of factor analysis for instrument development in health care research. London: Sage Publications. https://doi.org/10.4135/9781412984898

Pillai R, Al-Malkawi HAN (2017) On the relationship between corporate governance and firm performance: Evidence from GCC countries. Research in International Business and Finance 44 (July 2017): 394-410. https://doi.org/10.1016/j.ribaf.2017.07.110

Qian M, Yeung BY (2015) Bank financing and corporate governance. Journal of Corporate Finance 32: 258-270. https://doi.org/10.1016/j.jcorpfin.2014.10.006

Rezaee Z (2008) Corporate governance and ethics. Hoboken, NJ: John Wiley \& Sons.

Salim R, Arjomandi A, Seufert JH (2016) Does corporate governance affect Australian banks' performance? Journal of International Financial Markets, Institutions and Money 43: 113-125. https://doi.org/10.1016/j.intfin.2016.04.006

Stewart JC (1981) Company tax - effective tax rates on profits. Journal of the Statistical and Social Inquiry Society of Ireland 24 (3): 101-134.

Tarchouna A, Jarraya B, Bouri A (2017a) How to explain nonperforming loans by many corporate governance variables simultaneously? A corporate governance index is built to US commercial banks. Research in International Business and Finance 42 (July): 645-657.

https://doi.org/10.1016/j.ribaf.2017.07.008

Tarchouna A, Jarraya B, Bouri A (2017b) How to explain nonperforming loans by many corporate governance variables simultaneously? A corporate governance index is built to US commercial banks. Research in International Business and Finance 42 (September 2016): 645-657.

https://doi.org/10.1016/j.ribaf.2017.07.008

Vu NH, Nguyen T (2017) Impacts of corporate governance on firm performance. Master's Program in International Strategic Management. Lund University.

Waweru NM (2010) The origin and evolution of management accounting: a review of the theoretical framework 8 (3): 165-182.

Yermack D (1996) Higher market valuation of companies with a small board of directors. Journal of Financial Economics 40 (2): 185-212. https://doi.org/10.1016/0304-405X(95)00844-5 
Zagorchev A, Gao L (2015) Corporate governance and performance of financial institutions. Journal of Economics and Business 82: 17-41.

https://doi.org/10.1016/j.jeconbus.2015.04.004
Zagorchev A, Gao L (2016) Journal of Economics and Business Corporate governance and performance of financial institutions. Journal of Economics and Business 82 (April): 17-41. https://doi.org/10.1016/j.jeconbus.2015.04.004

\section{APPENDIX: Definition of Variables used in the studies}

\begin{tabular}{|c|c|c|c|}
\hline Variable & Code & Description & Prior studies \\
\hline \multicolumn{4}{|l|}{$\begin{array}{l}\text { Firm } \\
\text { Performance }\end{array}$} \\
\hline Return on Asset & ROA & $\begin{array}{l}\text { The ratio of profit before tax to } \\
\text { total assets }\end{array}$ & Detthamrong et al. (2017), Munisi and Randøy (2013), Lasfer (2006) \\
\hline Return on Equity & ROE & $\begin{array}{l}\text { The ratio of profit before tax } \\
\text { to equity }\end{array}$ & Adams and Veprauskait (2013) \\
\hline \multicolumn{4}{|l|}{$\begin{array}{l}\text { Corporate } \\
\text { Governance }\end{array}$} \\
\hline $\begin{array}{l}\text { Board } \\
\text { Magnitude }\end{array}$ & BS & The total board members & Adams and Veprauskait (2013), Vu and Nguyen (2017) \\
\hline $\begin{array}{l}\text { Independent } \\
\text { Director }\end{array}$ & BIN & $\begin{array}{l}\text { The ratio of independent } \\
\text { director to total board }\end{array}$ & Ciftci et al. (2019) \\
\hline $\begin{array}{l}\text { Board } \\
\text { Engagement }\end{array}$ & BM & $\begin{array}{l}\text { Number of meetings held } \\
\text { yearly }\end{array}$ & Adams and Veprauskait (2013) \\
\hline $\begin{array}{l}\text { Director } \\
\text { Ownership }\end{array}$ & $\mathrm{DOH}$ & $\begin{array}{l}\text { Percentage of number of } \\
\text { shares held by directors to } \\
\text { total shares }\end{array}$ & García-Meca et al. (2014) \\
\hline Board Insider & BI & $\begin{array}{l}\text { The ratio of executive directors } \\
\text { to board magnitude }\end{array}$ & Bird et al. (2015) \\
\hline $\begin{array}{l}\text { Board } \\
\text { Committee }\end{array}$ & $\mathrm{BC}$ & Number of Board Committees & García-Meca et al. (2014), Zagorchev \& Gao (2016) \\
\hline $\begin{array}{l}\text { Condensed } \\
\text { Governance } \\
\text { Indicator }\end{array}$ & Index & $\begin{array}{l}\text { Corporate governance Index } \\
\text { generated by Principal } \\
\text { Component Analysis }\end{array}$ & Tarchouna et al. (2017b), Armstrong et al. (2015) \\
\hline \multicolumn{4}{|l|}{$\begin{array}{l}\text { Firms } \\
\text { Characteristics }\end{array}$} \\
\hline Tangibility & Tan & $\begin{array}{l}\text { The ratio of total fixed assets to } \\
\text { total assets }\end{array}$ & Huang and Kang (2017a), Detthamrong et al. (2017) \\
\hline $\begin{array}{l}\text { Capital } \\
\text { Ownership }\end{array}$ & Own & $\begin{array}{l}\text { The ratio of shareholders' fund } \\
\text { to total assets }\end{array}$ & Zagorchev and Gao (2015) \\
\hline Firm size & Size & Natural logarithm of total asset & Munisi and Randøy (2013) \\
\hline Listed Date & Age & $\begin{array}{l}\text { Natural logarithm of number } \\
\text { of years listed }\end{array}$ & Detthamrong et al. (2017), Ararat at al. (2017) \\
\hline Leverage & Lev & $\begin{array}{l}\text { The ratio of total debt to total } \\
\text { assets }\end{array}$ & Munisi and Randøy (2013), Lasfer (2006) \\
\hline
\end{tabular}




\section{Notations}

Variables and functions

$R O A$ - The ratio of profit before tax to total assets;

$R O E$ - The ratio of profit before tax to equity;

$B S$ - The total board members;

$B I N$ - The ratio of an independent director to total board

$B M$ - Number of meetings held yearly;

$\mathrm{DOH}$ - Percentage of the number of shares held by directors to total shares;

$B I$ - The ratio of executive directors to board magnitude;

$B C$ - Number of Board Committees;

Index - Corporate governance Index generated by Principal Component Analysis

Tan - The ratio of total fixed assets to total assets;

Own - The ratio of shareholders' fund to total assets;

Size - Natural logarithm of the total asset;

Age - Natural logarithm of the number of years listed;

Lev - The ratio of total debt to total assets.

\section{Abbreviations}

PCA - Principle Component Analysis. 